起向する点にわれわれは特に注目している，

質問 佃守(横市大)。1.椎骨動脈撮影で angiospasmus 等の異常所見はどうだったのか？．2、外科では 星状神経節 block 前後で指尖脈波の対比索行うが, bleck 前㣪の E.N.G 対比は行われたか？

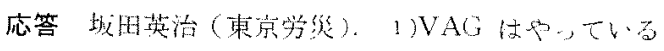

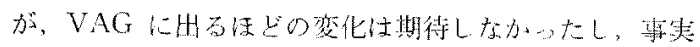
みら机なった。2)神経ブロックはやっているが，その 前㣪の ENG

(B $80-1067-12510$ )

\title{
23. 主婦における非前庭性めまいについての一心身医学的考察
}

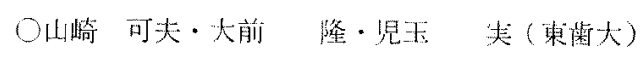

はじめに：非前庭めまいの中には心身医学的アプロー 千在要上するものが少がずあることについて什以前 泟古述心场。

一般に心身医学的治療が奏効し寛解した埸合、㮔々の

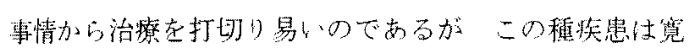
解上いら言葉が示すごとく、再発の叮能性が非常に大で あるため，筧解後のフォロー・ナップがきわわて電要上 なる。しかも，之の最小期間上してはどの程度が必要で あるのか非常に難しい，一般論上して仕々一ス バイ ケースということになるのは事䒠であるが、大体の目晏 をつけてみたい上いらことで過去10年余にわたり研究赏 つふけてきた。

われわれの経娩ではそのフォロー・アップの期間が

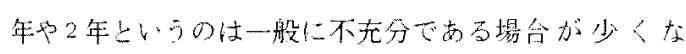

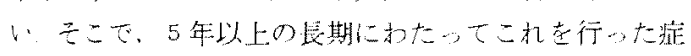
例在中心上して追究して双た。

研究方法：1)娰象：1960年10月1日上り1970年东で

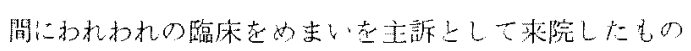

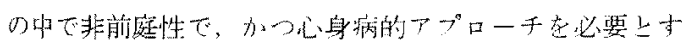

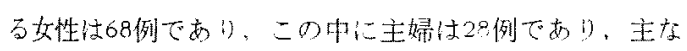
心因方家庭内の夫にあるものは19例であり，赛解徣5年 以上のフナローナップできたもの仕わすか8例であ， た.

この8例を中心しして種々换討した。

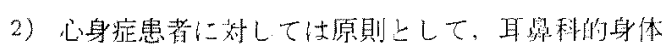

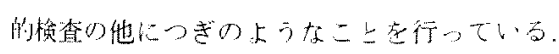

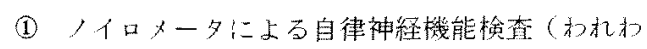
礼の法)

(2)心理テスト (C.MI，Y（G，夺の他)

(3) 血居の变動

(4) 脈搏の変動

(5) 体温の㸓野

(6) セルシン インタビー
(7) 周四の人々上のインタビュ-

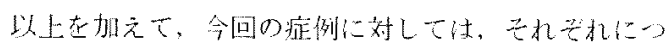

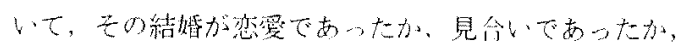
またそのおのおうにい、ての期間、反刘たた者が双少の

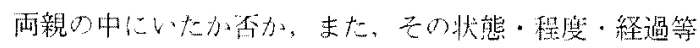
につマても調心た。

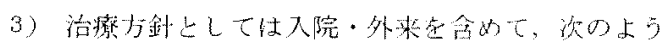
1行一飞いる.

(1) ×イロ:50〜200mlの静注または点注 (2)心

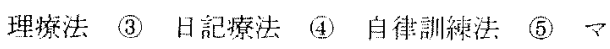
イナートランキライザー(セルシン セレナー

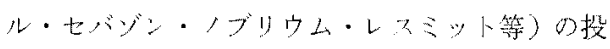
与. (6) 腎境の改盖の方法

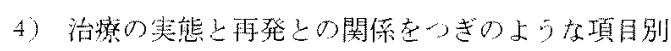

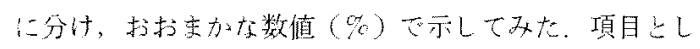
ては,

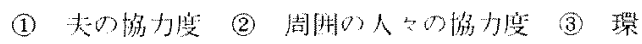

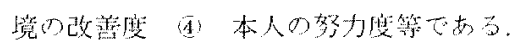

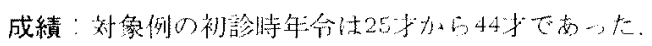

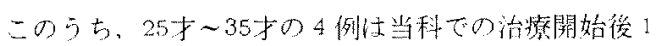
年弱で筧解し, 支の传5〜7年間のつナローアップて

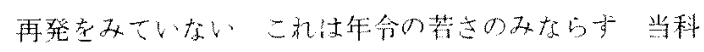

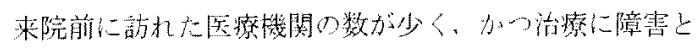

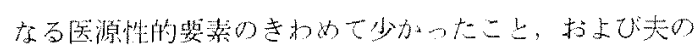

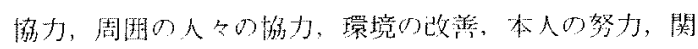
係者の本症に对する理艧等吕光分であのたこ上によると 若える。

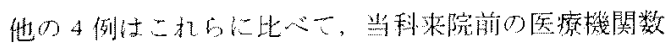

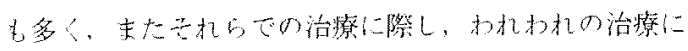

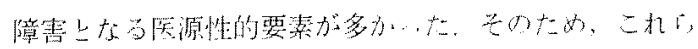

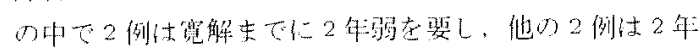
手在慗した。

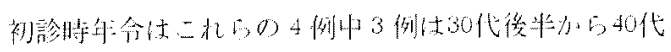


であり、1例のみ31才であったが、この症例は28才の上 きに子宮全摘出術が行われていた。

また後の４例に拁いては人, イロメーターに上る自律神 経機能テストでも，比較的嘼度の障害があり，ホルモン のバランスの失調の程度も前述の4例に比して高度であ った.

結語：われわ机が取报うここのできる症例は，乙の数 に标いて，捄のずと限界があり，絬論在だすには少数で あるため，今回の8 例を中心としてここれに加えてれれ わ机の10年余の経験至主体として若干の傾向捉えるこ 上ができたので，その概略老述心゙た。

1）発症の特徴的傾向としての主な条件的因子.

(1) 恋愛結婚の場合に好発する。しかも双方の再親 の中に反対した者がいる場合にはさらに好発す る. (2) 見合い結婚の場合には少いしかし，政 略的結婚や一方のエゴイズム的結婚の場合には好 発寸る、(3) 夫が趿務先で，、和非る仕事の鬼上 いわれ，そ机自他上もに認めている場合に㧈い て, その妻に好発する。

2）効果に拉上ぼす特徽的㑯向を示寸主な条件的因 子.

(1) 效果に正比例的䝨向を示すもの，(a) 年令の若 さ（b）夫の協力度と周囲の人々の協力度との総 和 (c) 心理療法や自律訓練法を積極的に行っ たか否か（d）家庭に対する適切な配感の程度

(2) 再発に正比例的傾向走示すもの (a) 環境の改 善度 (b) 本症に対する理解度（関保者）

以上，要するに治療中に拁いて，すでに再発の傾向の 強いものとそうでないものとはあらかじめ，ある程度の 予測が可能である。したがって，再発の可能性の強いも のに対しては最低 5 年間のフォロー・アップは必要であ 万5上考允ている。しかし再発の可能性の少いものにつ いては若下期間の短縮は可能であるが，その基準につい ては今娞さらに検封を加えた上で，いずれ発表する。

質問 滝口唂（広島市民病院），非前庭性的末以と いうのはどの蝩用を示しているか。，心因性めまいと同一 のものか否か。患者が内観に達したか否か。

応答山崎可夫(東歯大)。(1)非庭性めまいの中て PSM 的厂プローチを必要上するもりを選んだ。(2)内曁 が早いものと遅いものがある。(3)宽解までに日数の加 ったものは来院前の医学性的要素上環境の改善の不備, その他がある。

(B $80-1069-25599)$

\title{
24. 胃疾患にともならめまいの臨床的, 実験的検討
}

\begin{abstract}
品石 司・日根 其二・仁木 宏・桂 周良・宇高二良・零 俊一・今井 義礼 宮武 公・高石 秀峰・元木 章二（德島大）・石田 美夫・加藤 律子(高松市民)
\end{abstract}

われわ机は胃の透視に際してバリウム服用後にめまい 感㧍よび平衡失調が增大また社出現したと訴えるめまい 患者に遭遇した。この患者に胃の透視時と同一条件下に バリウムを同量服用させその前後でめまい平衡失調の変 動を測定した結果バリウム服用によりめまい感の軽度な

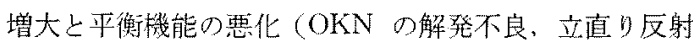
の琹化）を証得た、この事実は胃に加わった何らかの 刺激がひき金上なりこの患者のめ东い平衡失調志顕現化 させたと考元られる。この孝えの变当性を㭲討する目的

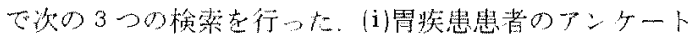

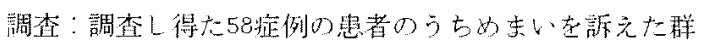
は39例 $(67 \%)$ ぬい在培えなかった群19例 (32\%)て あった，陮伴症状として，首，肩こり腰痛など顴部腰部 顿部支持組䋨案張光谁症状在伴ったものは，めまい群 (25/39) 64\%非め屯い群 $(9 / 19) 47 \%$ でありその差17
\%であった，耳鳴，難聴を伴ったものは好まい群（11/ 39) $28 \%$ 非めまい群 (4/19) $21 \%$ でありその差は $7 \%$ で あった，血圧の異常在伴ったものは高血圧はめまい群 (5/39) 13\%非めまい群 $(1 / 19) 5 \%$ でありの差8\% であった，低血圧はめまい群（19/39）49\%非めまい群 (2/19) 11\%でありその差37\%頭痛を伴うものはめまい 群 (17/39) 44\%非交い群 (0/19) 0\%でその差44\%,

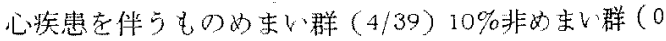
10）。\%でありての差10\%であった，以上の成績から 简疾患患者にはめ东いを訴える者は子想外に多いこ上， そしてこれらのめまい群では頭痛, 低血圧, 顧部腰部軟

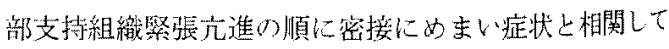
いることが判明した。この事実は頭痛，頚部腰部赖部支 持組織の祭張筫常などが慢性的に存在するために生ざた 視床下部脳幹系の機能低下と胃障害が相伴ってめまいを 